\title{
Knowledge Sharing in IT Consultant and SME Interactions
}

\section{Adrian Bradshaw}

J ames Cook University, Singapore

adrian.bradshaw@jcu.edu.au

\author{
Venkateswarlu Pulakanam \\ University of Canterbury \\ venkat.pulakanam@canterbuty.ac.nz
}

\author{
Paul Cragg \\ University of Canterbury \\ paul.cragg@canterbury.ac.nz
}

\section{Abstract}

Many small and medium enterprises (SMEs) depend on consultants to overcome knowledge barriers, especially for IT projects. This paper aims to determine how IT consultants affect the IT knowledge of SMEs when IT consultants and SMEs interact. Data were collected using faceto-face interviews with both IT consultants and SME managers. The study is the first to identify what and how SMEs learn from consultants during an IT implementation project. Consultants help SMEs gain different types of knowledge, employing a broad range of knowledge sharing mechanisms. As consultants are an important part of the knowledge creation processes of SMEs, SMEs should strive to form long-term relationships with consultants and use these interactions to develop IT knowledge within the SME.

Keywords: Knowledge sharing mechanisms; Knowledge Assets; IT projects; IT Consultants; SME; Accounting Information Systems.

\section{Introduction}

External experts are important to many small and medium sized enterprises (SMEs) for successful IT implementation (see seminal work by Soh et al. 1992, Thong et al. 1994 \& 1997, Otiz de Guinea et al. 2005). The main reason why external experts like consultants are necessary is because SMEs face knowledge barriers and depend on consultants to overcome these barriers (Thong 2001; Nevo et al. 2007; Carey 2008 and Chen et al. 2008). In helping SMEs to overcome knowledge barriers, consultants act as bridging intermediaries, in which they disseminate specialised knowledge and share ideas and experiences (Carey 2008).

While many SMEs "hire know-how" from advisors and consultants, it has been reported in the literature that SMEs were not effective at leveraging knowledge from external parties (Chen et al. 2006, p9). This finding highlights the need and importance of understanding how the use of consultants influences the growth of IT knowledge in SMEs. As a first step, it is necessary to understand the processes by which knowledge is acquired and shared, as well as the barriers to knowledge in organisations (Yeşil \& Hirlak 2013). In addition, it is further necessary to understand the types of knowledge that consultants help SMEs to create. This is important as it may assist SMEs to develop strategies to overcome their lack of IT knowledge.

In today's fast changing business landscape, knowledge-based resources and processes may be the key to business performance improvement (Schiuma 2012). Accordingly, SMEs have to find ways to adequately manage this aspect, which involves knowledge identification, knowledge storage/retention, knowledge utilisation, knowledge creation and knowledge sharing. Managing IT knowledge in SMEs may be particularly challenging because of the reliance of SMEs on IT consultants to help them overcome their lack of IT knowledge.

This paper therefore seeks to determine how IT consultants affect the IT knowledge of SMEs, from studying the interaction between consultants and SMEs. Knowledge creation/transfer (Nonaka \&Toyama 2005) and knowledge sharing mechanisms (Boh 2007; Boh \&Wong 2013) 
are used to understand how SMEs create IT knowledge with the assistance or influence of consultants.

This research is important as it focuses on two sectors of national importance; that is, the SME sector and the IT services sector. First, this research is of interest to the SME sector, which plays a significant role in many national economies (Taylor \& Murphy 2004). For example, in New Zealand in 2013, 99 percent of enterprises were SMEs with fewer than 50 employees (Ministry of Business, Innovation and Employment [MBIE] 2014). Similarly, in many countries, SMEs account for a very high percentage of firms.

Second, the research extends IT services research, which is currently weak. This weakness may be a result of the relatively recent and rapid growth of the IT services sector, which has also become important to many national economies. IT services are considered essential for improving business processes and infrastructure, especially in the context of economies dominated by SMEs (Nevo et al. 2007; Hu et al. 2014). IT services is an important industry subsector within the IT sector. For example, according to The New Zealand Sectors Report 2013: Information and Communication Technology' (MBIE 2013), in New Zealand in 2012, 83 percent of all IT firms were in IT services (which includes IT product firms) and, $42 \%$ of all angel and venture investments were in IT systems and IT service sectors. Also, according to this report, the IT sector was "a story of success" and employment growth was driven by Telecommunications and IT services. Further, IT is a fast growing industry sector in many countries (OECD 2012). Many SMEs are clients of the growing IT services sector, so this research is important as it focuses on these two sectors. The many IT consultants who are providing IT services to SMEs need research relating to them.

Lastly, the research adds to the understanding of knowledge sharing and management within the context of IT consultant and SME interactions. In today's rapidly changing business environment, knowledge and knowledge management play a critical role in improving productivity and maintaining competitiveness. In this paper, IT implementation refers to the process where a software system or solution is sourced, installed and configured within an organisation. IT implementation in this study focuses on short-term projects where external IT specialists (consultants) provide services for the purpose of implementing IT solutions at the contracting SME. Large scale outsourcing projects, long-term (multi-year) service agreements and on-demand technical services are excluded (Nevo et al. 2007).

For this study, an IT consultant is viewed as any individual or organisation contracted to assist SMEs with the implementation of IT. These include mega-consultants, vendor-consultants, independent consultants and independent reseller-consultants (these categories are adapted from Basil et al. (1997) and are still relevant today. See Table 1 for a brief description of each category). The scope of the study included accounting practices, as many accounting practices act as IT consultants, and many accounting practices focus on SMEs. Also, some accounting practices encourage their clients to use specific software and offer software support. Thus, many accounting practices can be classified as either independent consultants or independentreseller consultants. 


\begin{tabular}{|l|l|}
\hline Consultant Type & Description \\
\hline Mega Consultants & Large companies that provide a variety of consulting services e.g. Deloitte \\
\hline $\begin{array}{l}\text { Independent } \\
\text { Consultants }\end{array}$ & $\begin{array}{l}\text { Small or large companies that provide consultancy services but are not } \\
\text { affiliated with any particular software vendor }\end{array}$ \\
\hline Vendor-Consultants & $\begin{array}{l}\text { Companies that provide consultancy services to support their software } \\
\text { solutions }\end{array}$ \\
\hline $\begin{array}{l}\text { Independent-reseller } \\
\text { Consultants }\end{array}$ & $\begin{array}{l}\text { Small or large companies that provide consultancy services and sell } \\
\text { software solutions but are not affiliated with any particular software } \\
\text { vendor }\end{array}$ \\
\hline Accounting Practices & $\begin{array}{l}\text { Accountants who encourage their clients to use specific software and offer } \\
\text { software support }\end{array}$ \\
\hline
\end{tabular}

Table 1. Types of IT consultants (Basil et al. 1997)

There is no established or widely accepted definition of small business. Curran \& Blackburn (2001) discuss that the definition of a small business may be based on the number of employees, on the organisation's financial turnover, or may be qualitative. In this paper, firms with fewer than 50 full-time employees, which account for $99 \%$ of all New Zealand enterprises, are considered as SMEs (MBIE 2014). This reflects the definition used by the Government of New Zealand, where our sample is based. Other countries have adopted different definitions for SMEs.

The rest of the paper is organised as follows: In the next section, we review the literature on consultant-client interactions in implementing IT projects, and knowledge creation and sharing. Then we describe the research objectives and methodology, before reporting case study findings. The latter sections of the paper discuss the study's contributions, limitations of the research, and suggestions for future research.

\section{Literature Review}

\subsection{IT Consultant-client Research}

Past research has recognised the importance and value of external experts to the implementation of IT in small or large organisations. Yet the pivotal role consultant engagement plays on the use and management of IT has not been fully researched. The extant research on consultant-client interactions is diverse, fragmented, sparse and sporadic (Ko et al. 2005; Swanson 2010; Lech 2011). The initial focus of consultant-client research was on consultant performance, based on client satisfaction (Haines \& Goodhue 2003; Yoon et al. 2004). More recent studies identify various intermediary roles of consultants (Howcroft \& Light 2008; Carey 2008) and examine the consultant engagement process (Chen et al 2008), consultant-client relationships (Nevo et al 2007) and the creation or transfer of knowledge (Lech 2011).

Six broad themes of extant research about IT consultants are presented in Table 2: Strategies for vendor, software and consultant selection; Functional activities, roles and responsibilities of IT consultants; Effectiveness of consultants and factors influencing IT success; Consultant engagement management including consultant-client relationships; Knowledge creation and transfer; and IT consultancy trends and other.

Table 2 cites about twenty studies, which support Swanson's (2010) view of limited research specifically related to IT consultants. It is also evident from Table 2 that much of the recent literature focusses on the impact of consultants on IT success in large organisations, and consultant engagement and consultant-client relationships in SMEs. Only two research papers 
(Ko et al. 2005; Lech 2011) focus on knowledge creation and transfer, with both addressing IT implementation in large organisations. Overall, most of the recent research is biased towards IT implementation in large organisations (see for example, Ifinedo (2011) and Lech (2013)).

\begin{tabular}{|c|c|c|c|}
\hline & SMES & $\begin{array}{c}\text { Large organisations } \\
\text { (may also include SMEs) }\end{array}$ & Other \\
\hline $\begin{array}{l}\text { 1. Strategies for vendor, } \\
\text { software and consultant } \\
\text { selection }\end{array}$ & $\begin{array}{l}\text { Gable (1991, 1996) } \\
\text { - MMCA }\end{array}$ & & \\
\hline $\begin{array}{l}\text { 2. Functional activities, } \\
\text { roles and } \\
\text { responsibilities of IT } \\
\text { consultants }\end{array}$ & & Lech (2013) - ES & \\
\hline $\begin{array}{l}\text { 3. Effectiveness of } \\
\text { consultants and factors } \\
\text { influencing IT success }\end{array}$ & $\begin{array}{l}\text { Soh et al. (1992) - } \\
\text { MMCA } \\
\text { Thong et al.(1994, } \\
\text { 1997) - MMCA } \\
\text { Thong (2001) - } \\
\text { MMCA }\end{array}$ & $\begin{array}{l}\text { Haines \& Goodhue (2003) } \\
\text { - ERP } \\
\text { Wang \& Chen (2006) - ERP } \\
\text { Ifinedo (2011) - ERP }\end{array}$ & Yoon, et al. (2004) \\
\hline $\begin{array}{l}\text { 4. Consultant } \\
\text { engagement process } \\
\text { including consultant- } \\
\text { client relationships }\end{array}$ & $\begin{array}{l}\text { Carey (2008) - } \\
\text { WD } \\
\text { Howcroft \& Light } \\
\text { (2008) - CR } \\
\text { Chen et al. (2008) } \\
\text { - ERP }\end{array}$ & $\begin{array}{l}\text { Chang et al. (2013) - ERP } \\
\text { Nevo et al.(2007) - IBS }\end{array}$ & \\
\hline $\begin{array}{l}\text { 5. Knowledge creation } \\
\text { and transfer }\end{array}$ & & $\begin{array}{l}\text { Ko et al. (2005) - ERP } \\
\text { Lech (2011) - ERP }\end{array}$ & \\
\hline $\begin{array}{l}\text { 6. IT consultancy trends } \\
\text { and other }\end{array}$ & & & $\begin{array}{l}\text { Basil, Yen, \& Tang } \\
\text { (1997) } \\
\text { Chen \&Wang } \\
\text { (2006) } \\
\text { Swanson (2010) }\end{array}$ \\
\hline
\end{tabular}

Table 2. Consultant-client research in the context of implementing IT projects (Where appropriate the specific IT projects studied have been identified: ERP = Enterprise Resource Planning; ES = Enterprise Systems; MMCA = Mini- and micro-computer application software; IBS = Internet business solutions; $\mathrm{WD}=$ Web design; $\mathrm{CR}=$ Customer relationship software)

Based on the summary provided in Table 2, there is a clear gap in research on knowledge transfer/creation, and the role of consultants in implementing IT in SMEs. It is this gap that this paper attempts to fill.

\subsection{Knowledge management and consultants}

Knowledge is an organisation's most valuable resource of lasting competitive advantage. It has become an area of interest for researchers in many disciplines over the years. Knowledge is defined differently depending on the context of the research. For example, Alavi \& Leidner (2001) define knowledge as "a justified belief that increases an individual's capacity to take effective action" (p109). On the other hand, Beesley \& Chalip (2011) define knowledge as "Information with meaning that exists within the individual" (p328). Nonaka, Krogh \& Voelpel (2006) recognise that knowledge can exist in two forms, explicit or tacit. Nonaka et al. (2006) point out that knowledge that can be uttered, formulated in sentences or captured in drawings and writing is explicit; knowledge tied to the senses, movement skills, physical experiences, intuition or implicit rules of thumb is tacit.

SMEs do not manage knowledge in the same way as larger organisations (Desouza \& Awazu 2006). Importantly, socialisation dominates the knowledge creation process in SMEs, and they tend to lack knowledge repositories. "Technology is never made part of the knowledge 
management equation" (Desouza \& Awazu 2006, p40). The socialisation mode involves sharing tacit knowledge among individuals (Nonaka et al. 2006). Alavi \& Leidner (2001) note that knowledgetransfer occurs: between individuals; from individuals to explicit sources; from individuals to groups; between groups; across groups and from groups to the organisation. Consequently, consultants, as intermediaries, have a key role to play in the knowledge transfer and knowledge creation process in SMEs. Howcroft \& Light (2008) argue that consultants act as 'conduits' by standing between IT suppliers and SMEs, where they provide services such as advice to assist with finding appropriate products, the implementation and customisation of the products, training and support services and the integration of software with existing systems. It is conceivable that during the SME-consultant process the transfer of knowledge occurs, a point that Carey (2008) underscores by describing consultants as bridging intermediaries who disseminate knowledge.

Therefore, it is argued that the use of consultants for the IT implementation process is a key part of the knowledge creation/transfer process in SMEs and consequently crucial to the organisation's knowledge management practices. This view is supported by Durst \& Edvardsson (2012) who call for studies that examine both sides of the knowledge sharing process in SMEs; that is, both sender (for implementation projects this would be the consultant) and receiver (SME).

\subsection{Knowledge creation and sharing}

In this paper we equate knowledge transfer with knowledge sharing, as do other researchers (see Ko et al. 2005). Knowledge transfer is defined in many ways but essentially it involves an exchange of knowledge from giver to receiver (J elavic 2011). It is purposeful, particularly in the implementation of IT systems and creates value for the client organisation. The core concept of knowledge transfer in IT system implementation is to ensure the effective application of the respective IT systems in the client organisation (Werner et al. 2014).

IT implementation is knowledge intensive. Within this setting, knowledge transfer happens in two directions: business knowledge transfers from client to consultant; and IT technical knowledge transfers from consultant to client (Lech 2011). The transfer of knowledge from consultant to client is the focus of this research. But how is knowledge created and shared? Nonaka \& Takeuchi (1995) proposed a unified model of organisational knowledge creation and transfer, and argued that knowledge was created through the interaction and intersection between tacit and explicit knowledge. The researchers noted that these interactions occurred along four modes: Socialisation; Externalisation; Combination; and Internalisation. This is referred to as the SECI model. Socialisation is the process of converting new tacit knowledge into the existing base of tacit knowledge. Externalisation is the process of articulating tacit knowledge into explicit knowledge. Combination is the process of converting explicit knowledge into more complex and systemic sets of explicit knowledge. Finally, internalisation is the process of embodying explicit knowledge into tacit knowledge.

Drawing on the knowledge management literature, Boh \& Wong (2013) propose a framework of knowledge sharing mechanisms, to reflect how knowledge is shared. Boh \& Wong (2013) define knowledge sharing mechanisms as "organizational practices adopted to facilitate the sharing, integrating, interpreting, and applying of know-what, know-how, and know-why embedded in individuals and groups" (p123). Boh \& Wong identify two dimensions to their framework: codification versus personalisation, and formal versus informal. The result is a two-by-two framework with four quadrants, which they refer to as quadrants 1 to 4 (Table 3). 


\begin{tabular}{|c|c|c|}
\hline & Informal & Formal \\
\hline Personalisation & Quadrant One Mechanisms & Quadrant Two Mechanisms \\
\hline Codification & Quadrant Four Mechanisms & Quadrant Three Mechanisms \\
\hline
\end{tabular}

Table 3. Knowledge Sharing Mechanisms Framework (Boh 2007; Boh \&Wong 2013)

Their quadrant 1 (informal personalisation) focuses on informal person-to-person knowledge sharing, such as chatting in cafes, hallways and at social events. By comparison, quadrant 2 (formal personalisation) reflects arranged sessions for person-to-person interaction, such as training sessions, joint exercises and communities of practice. Their quadrants 3 and 4 reflect codification rather than personalisation. Codification is where knowledge is "carefully articulated, captured, and stored in documents and databases" (p126). Quadrant 3 (formal codification) focuses on person-to-document knowledge sharing, and includes organisationwide repositories and intranets. Quadrant 4 (informal codification) covers informal and adhoc exchanges of documents, reflecting a tendency for people to use personal contacts for documents rather than electronic databases (quadrant 3). This framework is particularly useful, and more suitable for our purposes, as the four quadrants cover the range of knowledge sharing contexts that occur during a typical consultant driven IT implementation.

\subsection{IT implementation and Knowledge Assets (KAs)}

If knowledge transfer/creation is an important aspect of the knowledge management (KM) process (Durst \&Edvardsson 2012), then the outcomes of knowledge transfer/ creation are the necessary target of the knowledge identification, knowledge storage/ retention and knowledge utilisation processes of KM.

The outcomes of knowledge transfer/ creation are knowledge assets (Nonaka et al. 2006). From a knowledge-based perspective, knowledge assets are either the inputs or the outcomes of knowledge creating processes within the firm. Nonaka et al. (2000) identify four types of knowledge assets: experiential; conceptual; systemic; and routine. Experiential knowledge assets consist of the tacit knowledge that is built through shared hands-on or working experience among individuals. Conceptual knowledge assets consist of explicit knowledge articulated through images, symbols and languages. Systemic knowledge assets consist of systematised and packaged explicit knowledge, such as explicitly stated technologies, product specifications, manuals, documentation and packaged information about customers and suppliers. Routine knowledge assets consist of the tacit knowledge that is embedded and regulated in the actions and practices of a firm.

Building on the idea that consultants disseminate specialised knowledge and are a part of the knowledge creation process, what knowledge assets result during an IT implementation project? Given the lack of IT knowledge in SMEs, and the knowledge dissemination ability of consultants, it stands to reason that various types of knowledge should be created in SMEs. The management of this newly created knowledge could have a major impact in helping SMEs overcome their knowledge barriers. The question raised here is supported by the finding of Durst \& Edvardsson (2012) who found there was little research on the types of knowledge provided in a firm, and on what types of knowledge was needed to deal with present and future business challenges. In the IT implementation context, this suggests that there is a need to know the types of knowledge that consultants disseminate to SMEs, as well as what types of knowledge are needed to help SMEs overcome their IT knowledge barriers.

In summary, it has been argued that knowledge transfer/ creation during IT implementation is an important aspect of the knowledge management process, and that consultants play a key part in the process. It has also been argued that there is a need to identify the types of knowledge assets resulting from the knowledge creation process, and a further need to identify which types of knowledge assets are beneficial to overcoming knowledge barriers in SMEs. 


\subsection{Research gap and modified framework}

Combining the concepts discussed above, and especially knowledge sharing mechanisms and knowledge assets, it is argued that the creation of knowledge assets can be related to knowledge sharing mechanisms. Since knowledge sharing mechanisms detail how knowledge is shared, and knowledge assets are the result of knowledge sharing/ creation, it seems likely that there should be an association between knowledge sharing mechanisms and knowledge assets. This implies that each knowledge sharing mechanism used by SMEs could result in the creation of knowledge assets.

In addition, since knowledge sharing mechanisms are generally defined as organisational practices used to facilitate the sharing of knowledge, and consultants disseminate knowledge, there are knowledge sharing mechanisms that may be influenced or even facilitated by consultants. This represents a point of departure from previous research. Prior research on knowledge sharing mechanisms has focussed on the advantages and disadvantages of various knowledge sharing mechanisms, the characteristics of knowledge sharing mechanisms, and more recently the classification of knowledge sharing mechanisms (Boh 2007) as well as the perceived usefulness of various types of knowledge sharing mechanisms (Boh \& Wong 2013).

In this paper we do not seek to investigate individually either knowledge sharing mechanisms, nor consultants, nor knowledge assets. Rather, we combine the creation of knowledge assets with knowledge sharing mechanisms to understand the knowledge sharing intermediary role of consultants and the impact of this role on SMEs. In particular we seek to understand how the knowledge sharing role of consultants leads to the creation of knowledge assets.

Table 4 is the general modified framework developed by combining knowledge sharing mechanisms from Boh \&Wong (2013) with knowledge-based theory (i.e. knowledge assets are the result of knowledge creation/ transfer).

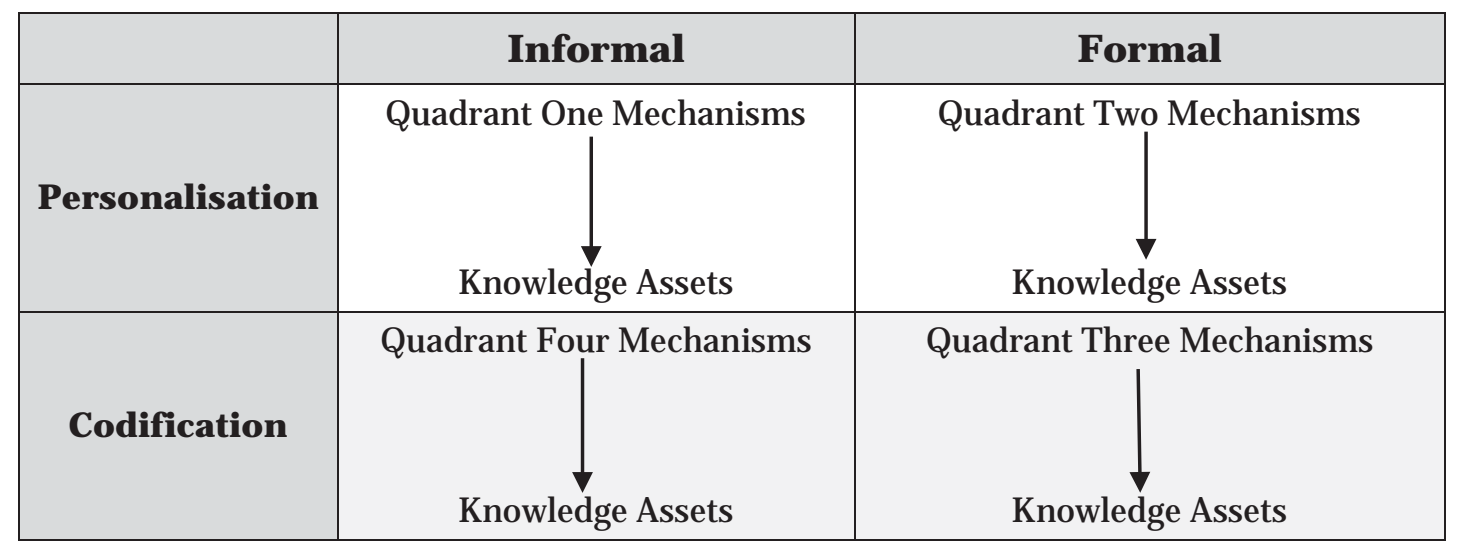

Table 4. Modified knowledge mechanisms framework

The concepts combined to create Table 4 have all been previously examined separately. Combining these concepts in the context of IT implementation and the use of consultants presents a unique opportunity to address the research gap previously identified pertaining to knowledge transfer/ creation, and the role of consultants in implementing IT in SMEs.

\section{Research Objectives}

This study aimed to address the following two research questions:

1. How do consultants share knowledge with SMEs during IT implementation projects?

2. What knowledge assets result from the knowledge sharing process between consultants and SMEs during IT implementation projects? 


\subsection{Research Methodology and Data Collection}

The context for the study was the implementation of IT by SMEs with the aid of consultants. The study was designed as a series of interviews with both sides of the IT implementation project; that is, IT consultants and SMEs. Consultants were treated as typical examples of individual consultants and were interviewed about their experiences with IT implementations with SMEs. In addition, each SME provided one example of an IT implementation project. In this sense, the unit of analysis for this research is the SME-consultant relationship. The case design follows the advice of Oates (2006) and Easterby-Smith et al. (2008), where case studies can take an in depth look at one, or even a smaller number of organisations, a department, an information system, or individuals. The case study method was selected as an appropriate approach because it allows IT implementation projects to be studied in their real-life context (Yin 2003). This approach allows a holistic view of the implementation process and the consultant-client interaction.

Accounting information systems (AIS) were chosen as they are widely used by SMEs. While some SMEs might use enterprise resource planning systems (ERPs) and others may use customer relationship management systems (CRMs), most SMEs would make use of AIS. Examples of off-the-shelf AIS packages often adopted by SMEs include MYOB, QuickBooks and Accredo.

The main criterion for selecting consultants was to consider consultants who primarily work with, and had previously implemented, AIS in SMEs. Consultants were chosen by first obtaining a list of accounting packages designed specifically for SMEs. Consultants were then randomly chosen, at least one for each of the packages used by SMEs. This was to ensure that the major accounting packages used by SMEs were accounted for in the study. Data were collected primarily by face-to-face interviews and supplemented by supporting material such as software brochures and company websites.

The main selection criteria for SMEs (service or manufacturing), was that the company had, with the assistance of a consultant, implemented, or was in the process of implementing, a new AIS or an upgrade of an existing system. Each SME had to meet the definition used in New Zealand for SMEs, ie, an independent firm with up to 50 employees (MBIE, 2014). SMEs were recruited using industry contacts.

The series of interviews with consultants represents the sender side of the knowledge transfer process, while the SME interviews represent the receiver side of the process. To ensure consistency between the two sides it was necessary to ensure that the implementation steps followed by consultants were the same. Consultants carry out the following steps or processes during implementation projects: (i) Initiation, (ii) Analysis and Recommendations, (iii) Installation, (iv) Configuration and Integration, (v) Training and (vi) Maintenance (On-going support).

It was important to establish that the implementation of the AIS followed the same steps. This meant that it was reasonable to assume that the SMEs would have experienced a similar implementation process. In essence, the implementation process can then be treated as a constant, making it easier to examine the consultant-SME interactions. It also meant that once consistent findings in the data were observed, it could be assumed that data saturation had been reached. Therefore the sample size for this research was not predetermined. We stopped collecting data from SMEs and consultants when we felt that we reached 'saturation' (Corbin $\&$ Strauss 2008); that is, when we felt that we were not gaining any more new insights from the data collected.

Tables 5 and 6 provide a summary of the consultants and SMEs involved in the study. Eight consultants were interviewed. These covered the range of types of consultants working with SMEs, and represented four of the major AIS used by SMEs. 


\begin{tabular}{|l|l|l|}
\hline \multicolumn{1}{|c|}{ Consultant } & Type of Consultant & \multicolumn{1}{c|}{ Expertise } \\
\hline Consultant1ABS & Reseller & QuickBooks \\
\hline Consultant2AP & Independent & MYOB \\
\hline Consultant3CAD & Accountant & MYOB \\
\hline Consultant4J K & Independent-reseller & MYOB \\
\hline Consultant5OW & Independent-reseller & MYOB \& Infusion \\
\hline Consultant6AIF & Independent & MYOB, Accredo \\
\hline Consultant7AT & Accountant & MYOB \\
\hline Consultant8ECR & Independent-reseller & MYOB, Accredo \\
\hline
\end{tabular}

Table 5. Summary of the eight consulting firms in the study

\begin{tabular}{|l|l|l|l|l|l|}
\hline \multicolumn{1}{|c|}{ SME } & $\begin{array}{c}\text { No. of } \\
\text { Employees }\end{array}$ & \multicolumn{1}{|c|}{ Sector } & $\begin{array}{c}\text { Type of } \\
\text { Consultant } \\
\text { Employed }\end{array}$ & \multicolumn{1}{|c|}{ AIS } & Interviewee \\
\hline SME1EAT & 50 & Manufacturing & $\begin{array}{l}\text { Independent- } \\
\text { reseller }\end{array}$ & QuickBooks & Accountant \\
\hline SME2ID & 6 & $\begin{array}{l}\text { Manufacturing } \\
\text { and Trades }\end{array}$ & $\begin{array}{l}\text { Independent- } \\
\text { reseller }\end{array}$ & MYOB & Manager \\
\hline SME3AMN & 7 & $\begin{array}{l}\text { Manufacturing } \\
\text { and Trades }\end{array}$ & Accountant & MYOB & Manager \\
\hline SME4AM & 16 & Manufacturing & $\begin{array}{l}\text { Independent- } \\
\text { reseller }\end{array}$ & Infusion & $\begin{array}{l}\text { Financial } \\
\text { Controller }\end{array}$ \\
\hline SME5DM & 11 & $\begin{array}{l}\text { Manufacturing } \\
\text { and Retail }\end{array}$ & Accountant & QuickBooks & Owner \\
\hline SME6SM & 30 & Manufacturing & $\begin{array}{l}\text { Independent- } \\
\text { reseller }\end{array}$ & Accredo & Owner \\
\hline SME7AG & 17 & Service & Accountant & MYOB & Manager \\
\hline
\end{tabular}

Table 6. Summary of the seven SMEs in the study

Seven SMEs were included for the receiver side of the knowledge transfer process. The largest SME had 50 employees and the smallest had 6 employees.

The primary data were collected via semi-structured interviews. The interviews were tape recorded with consent from the interviewees, and were approximately one hour in length. Two interview protocols were used; one for the consultants and one for the SMEs. For the SME interviews, the main persons who worked with the consultant on the project were interviewed. The interview questions were divided into three sections: (1) personal and company details, (2) implementation project details, and (3) knowledge assets. These sections applied to both the consultant and the SME interviews. A sample of the questions that guided each set of interviews is provided below. Most questions in sections 2 and 3 were used in an open-ended way, with sub-questions as prompts to gain a rich picture for the topic.

Consultant Interviews

1. How do you go about sharing hands-on accounting expertise with clients?

2. How do you ensure that the client gains accounting know-how?

3. Could you describe any organisational routines surrounding the use of the accounting system established by yourself? How are these routines established? 
4. How do you go about sharing your accounting skills and knowledge?

5. How do you ensure that the organisation makes use of information stored in the accounting database or data-store?

\section{SME Interviews}

1. Who were the main sources of hands-on accounting software experience (employees, partners, suppliers, consultants, accountants)?

2. How is the hands-on experience shared throughout the organisation?

3. How did you acquire your knowledge of how-to do accounting (know-how)?

4. Could you describe any organisational routines governing the use of the accounting software? How were these routines established? How are these routines shared among employees?

5. How do you make use of the information stored in the accounting database or datastore? How did the accountant assist you with this?

\subsection{Coding Process}

Data were collected primarily by interviews and supplemented by supporting material such as IT brochures and company websites. All interviews were recorded, transcribed and then analysed using TAMS Analyzer, a software for analysing qualitative data for Macintosh computers. Copies of the transcripts were given to the interviewees for their verification before the transcript was accepted for analysis.

Data were coded according to the predefined categories determined by the study framework (see Table 4). Data were mapped according to the major themes of the framework and this provided the initial coded lists. Each initial coded list was then recoded at a lower level to create subcategories or codes of the initial ones. Memos and annotations were used to assist in the recoding process. Within each group (that is, consultant interview data and SME interview data), searching and pattern matching were used to categorise the sender and receiver sides of the knowledge sharing process.

\section{Analysis and Findings}

The aim of this research was to investigate how knowledge was shared and what knowledge was shared during IT implementation projects. The case evidence was analysed using the modified framework of knowledge sharing mechanisms (Boh \& Wong 2013) and the types of knowledge assets identified by Nonaka et al. (2000). By following this approach the results reveal how knowledge was shared between consultants and SMEs, as well as the type of knowledge (knowledge assets) that resulted. Each of the four parts of the Boh \& Wong (2013) framework is discussed below, with the associated knowledge assets. Where a knowledge sharing mechanism is discussed, its corresponding quadrant (Q1, Q2, Q3, Q4) is displayed in brackets. The results are summarised in Table 7 (Knowledge sharing mechanisms and associated types of knowledge assets) and Table 8 (Example knowledge assets in consultant and SME interactions). 


\begin{tabular}{|c|c|}
\hline Quadrant 1. (informal personalisation) & Quadrant 2. (formal personalisation) \\
\hline $\begin{array}{l}\text { Mechanisms: Word of mouth sharing through } \\
\text { informal, one-on-one training sessions and } \\
\text { phone calls over a period of a few months; } \\
\text { that is, not just at the time of implementing } \\
\text { the system. }\end{array}$ & $\begin{array}{l}\text { Mechanisms: Formal training sessions by } \\
\text { consultants for SMEs, involving hands-on use of } \\
\text { the system, as well as discussion. Formal project } \\
\text { meetings, including project initiation, updates and } \\
\text { reviews. }\end{array}$ \\
\hline $\begin{array}{l}\text { Type of knowledge asset: experiential (know- } \\
\text { how to use the new system); systemic (reports } \\
\text { from the new system) }\end{array}$ & $\begin{array}{l}\text { Type of knowledge asset: experiential (know-how } \\
\text { to use the new system), and accounting knowledge } \\
\text { (how to undertake some accounting activities). }\end{array}$ \\
\hline Quadrant 4. (informal codification) & Quadrant 3. (formal codification) \\
\hline $\begin{array}{l}\text { Mechanisms: Written monthly checklist of } \\
\text { tasks. } \\
\text { Written tips and tricks. } \\
\text { Manuals written voluntarily. } \\
\text { Procedures written voluntarily. } \\
\text { Sharing documents informally, e.g., emails } \\
\text { sent from consultants to SMEs, e.g., on how } \\
\text { to do something. }\end{array}$ & $\begin{array}{l}\text { Mechanisms: Written, step-by-step } \\
\text { documents/ guides, including monthly checklist of } \\
\text { tasks, and tips and tricks. } \\
\text { Formal resources like user manuals, software } \\
\text { documentation, CDs, DVDs, and on-line help } \\
\text { Newsletters. }\end{array}$ \\
\hline $\begin{array}{l}\text { Type of knowledge asset: systemic ('how to' } \\
\text { documents); routine (accounting routines). }\end{array}$ & $\begin{array}{l}\text { Type of knowledge asset: systemic ('how to' } \\
\text { documents and manuals). }\end{array}$ \\
\hline
\end{tabular}

Table 7. Knowledge sharing mechanisms and associated types of knowledge assets

\subsection{Quadrant 1: informal personalisation}

Informal training was the main knowledge sharing mechanism; that is, knowledge was shared from consultant to SME mainly through informal training sessions. At the early part of the implementation project, training was formal (Q2), followed by numerous informal one-on-one sessions (Q1) over a period of months. Consultant4J K revealed,

“... generally $90 \%$ of the training that I do is out at the clients' workplace, one-onone training... showing them what to do."

Consultants provided verbal instructions and suggestions (Q1) to SME staff, who may in turn create written procedures of their own (Q4).

Much of the on-going contact was informal, with SME staff contacting consultants on a casual/ad-hoc (Q1) basis to seek advice, guidance and assistance with problems. Thus there was typically an on-going relationship between consultants and SMEs. Consultant4J K believed that on-going contact with the client was essential in the implementation process and noted that on-site visits, involving one-on-one training with SMEs, occurred over several months (Q1). Thus informal networks were created between consultants and some staff within each SME. The consultants did not help SME staff develop informal networks with users in other firms.

The consultants built up their own knowledge over an extensive period of time, especially on how to integrate and use the software in ways that achieved various goals in different SMEs. For example, consultants tried to ensure that SME staff had easy access to the knowledge stored in the accounting database. Consultant1ABS stated,

"I would, as part of the training, show them how to create the reports (an experiential KA), and explain the usefulness of those reports and why they exist and who usually would want information from those reports."

Similarly, Consultant3CAD pointed out, 
"So I'll sit down with them and find out what information they really want .... I go through with them the sort of standard reports (systemic KA) that they ought to be using so that they can get the information that they're looking for. I'd also make recommendations on the sort of reports that I think they ought to look at."

This on-going informal training by IT consultants resulted in SME staff becoming advanced users of the accounting system. Typically, at the start of a project, no SME staff possessed knowledge of how to use the new accounting software. During the project, SME staff not only acquired hands-on knowledge of how to use the new software (an experiential KA), but they also acquired broader know-how knowledge (an experiential KA). For example, at SME3AMN, staff learned how to use the system, then in later months gained data from the new system of their increased use of some products. They then used this product-use data to negotiatea better price with their supplier as they were using more of the particular product. The consultants facilitated the process of empowering users to use the software, and continually grow their hands-on knowledge. Consultants facilitated this process when they showed users how to createvarious reports, as well as which reports would be of value to their company. This knowhow/ how-to knowledge are examples of experiential KAs, while the report itself is an example of a systemic KA. SME staff learned how to make good use of the accounting database (e.g., to create a profit and loss report), which is new knowledge constructed out of the knowledge stored in the database.

Experiential knowledge assets dominate quadrant one activity, with some evidence of the use of systemic knowledge assets. The main example of experiential KAs was the know-how acquired by SME staff to use the new AIS. SME staff learned to use the software for various tasks with help from the consultant. Such shared experiences and activities facilitated the sharing and development of tacit hands-on knowledge. There was also evidence of systemic KAs resulting from quadrant one type mechanisms, especially where knowledge was packaged in the form of a report. Therefore, knowledge was shared between consultants and SMEs through the informal personalisation mechanism where experiential and systemic knowledge assets emerged (or were created as a result). Refer to Table 8 for a list of relevant experiential and systemic knowledge assets.

\subsection{Quadrant 2: formal personalisation}

The initial training sessions (Q2) tend to be structured, aimed at equipping SME staff with sufficient hands-on knowledge to use the software. SME staff gained this new knowledge from face-to-face contact, rather than from reading books or manuals. In addition, some SME staff attended training sessions held by the software suppliers.

Formal meetings were another quadrant two mechanism used by consultants. Several formal meetings took place involving consultants and SME staff. These meetings occurred throughout the course of a project; for example, initiation, update and review meetings, and follow-up meetings after the completion of the project. Consultant4J K noted that they had follow-up meetings designed to ensure that SMEs were progressing well with the software. SME3AMN noted that they had regular quarterly meetings with the consultant, who was also their accountant. SME2ID stated that since the completion of the project, the consultant made a scheduled yearly visit to review how staff were progressing and to address any issues.

SME staff watched, practiced, listened and interacted with the consultants (Q2). It was through these interactions, both prior to implementation and during the implementation, that SMEs gained know-how knowledge of accounting, the use of accounting software, and the potential benefits and implications of using the software. These types of know-how knowledge are examples of experiential KAs. Therefore, knowledge was also shared between consultants and SMEs through the formal personalisation mechanism, and experiential knowledge assets were the main outcome of this knowledge transfer or sharing. 


\subsection{Quadrant 3: formal codification}

The consultants often provided written step-by-step documents or guides (Q3) to help SMEs build their hands-on expertise. This is an example of a formal codification mechanism. Boh \& Wong (2013) define knowledge that is shared through a codification mechanism as knowledge that is carefully codified and stored in databases and documents. The codified knowledge can then be accessed and used easily by employees.

The consultants also provided written tips and tricks (written documents are an example of systemic KAs). Consultant4J K generally left new clients with "six or seven pages" of guidelines as "basic knowledge, how to do this, how to do that". Consultant5OW provided "a step-bystep guide of basic knowledge to help get them started" (all examples of systemic KAs). Consultant1ABS aimed to "try and break it down into as many small steps as possible and try and layout the process for them to get their work done." Consultant7AT referred to the written document as "business best practice". "For example, as part of the follow up (Q2), we have the monthly checklist and the instructions (Q3)." The checklist provided by the consultant would be a list of tasks that SMEs were expected to undertake each month.

Consultants also made other quadrant three type resources available to SMEs, including software documentation, manuals, CDs, DVDs, newsletters, and on-line help (all examples of systemic KAs). For example, the manager of SME2ID used the software manuals to teach himself how to use the software. Newsletters were also used to pass information onto SMEs. The newsletters were published by the various software vendors and consultants to make these available to the SMEs.

The trend appears to be that online help, either as part of the software or over the Internet at the vendor's site, has replaced manuals and other materials. Printed manuals and CDs were still provided by some vendors. Where this was the case, consultants ensured that this material was given to SMEs. It should be noted that formal and informal training, and the use of routine documents and procedures were more commonly used than software manuals and CDs.

Although consultants informed SMEs about the online documentation and manuals, only SME2ID reported using the software manuals. Furthermore, very few SME staff used on-line help or any documentation that may have been included with the software. Consultant1ABS stated that "... the books and CDs, they get put on a shelf and never looked at again." Consultant2AP noted that very few people used the actual reference material. He pointed out that, "They don't want to fool around and look in a book, go on a website; it might or might not work, and all the rest of the drama that goes with it." Consultant3CAD said that, although he supported the notion that reference material was not used, he also noted,

"What I find is that it varies from person to person. Some people really like to use the help; other people will just pick up the phone and phone me. Yeah, it really does vary."

Systemic knowledge assets dominated quadrant three. Systemic knowledge assets consist of systematised and packaged explicit knowledge. This kind of knowledge is relatively easy to communicate, store, and distribute. Examples of systemic knowledge assets included the software database, reports, online help documents and other documents provided by consultants. These would be documents such as routines and procedures for the accounting function and use of the software such as tips and tricks, "how-tos", step-by-step guides and best practice guides codified by consultants. Thus consultants used the knowledge and experience they had to assist SMEs by providing tailored solutions to meet the needs of each SME. Therefore, the formal codification mechanism resulted in systemic knowledge assets.

\subsection{Quadrant 4: informal codification}

As the SME staff became more confident in using the software, and as the use of the software became embedded in their daily routines, SME staff created their own written documents detailing routines and procedures. Thus it was common for SME staff to create their own set of notes to guide them (Q4), especially in a range of periodic (daily, weekly, etc.) routine 
activities related to using the system. This point was best captured in the following quote from Consultant5OW,

"So they will either write it out as you work through it with them: so they'll essentially write their own procedure for it, but you work with them while they're doing that. I find that better because the way I word something may not be the way they would word something; so if I do it for them they may not understand that when I'm not there. So it's better to be written in their words so that they can then use it in hindsight."

Consultant1ABS indicated,

“I usually recommend a process. I haven’t formalised it with documentation.... but I would usually recommend it verbally and get them to write it down."

Consultant3CAD stated that he had no formalised routines but would "... go over with the client what is needed to be done daily, weekly and monthly," and recommended to the client the necessary procedures to follow. Consultant4J K stated that, with new clients, who were usually unaware of how the entire accounting process worked, she recommended a basic bookkeeping routine to help with their needs.

Routine knowledge assets are embedded and regulated in the actions and practices of a firm and consist of know-how, working practice and organisational routines for carrying out dayto-day activities (Chou \& He 2004). This is knowledge that is embedded in day-to-day activities, including the accounting routines SME staff carry out on a daily or periodic basis. Therefore, while the procedures and routines written by staff are considered systemic knowledge assets, the know-how gained from the practice or execution of the routines would be considered routine knowledge assets. Therefore, the informal codification mechanism gives rise to systemic and routine knowledge assets.

\begin{tabular}{|l|}
\hline Knowledge Asset Outcomes \\
\hline Experiential KAs \\
1. Gain know-how and hands-on-knowledge of the use of AIS. \\
2. Using the system to connect with customers \\
3. Use, potential benefits and implication of using the software \\
a. How much one client is purchasing more than the other \\
b. Visibility of raw material used, which helps to re- negotiate price \\
4. Accounting knowledge \\
5. Trust \\
6. Improvisation \\
\hline Systemic KAs \\
\hline 1. Types of customised reports of value to SME \\
2. Routine documents or procedure documents \\
3. Basic knowledge guides of how to do (breakdown into small steps) \\
4. Generate new customised reports, including profit and loss reports \\
5. SME writes routine documents or procedure documents \\
\hline Routine KAs \\
1. Daily, weekly and monthly routines of the accounting function \\
2. Invoicing, accounts payable, payroll routines
\end{tabular}

Table 8. Example knowledge asset outcomes in IT consultant and SME interactions

It is worth noting that in practice, Boh \& Wong (2013) found it hard to differentiate between quadrants 1 and 4 as "knowledge exchange via informal codification mechanisms tends to 
take place concurrently with informal personalisation mechanisms" (p131). When individuals share knowledge, they often discuss (quadrant 1) and exchange documents (quadrant 4). For example, during informal discussion and one-on-one training (quadrant 1) the consultant may produce written tips and tricks (quadrant 4). However, a number of documents were created by the employees of the SMEs, for example manuals written voluntarily. This made it easier to differentiate between quadrants 1 and 4 .

\section{Discussion}

This study makes two significant contributions. First it improves our understanding of 'how' SMEs acquire knowledge from IT consultants. Secondly, the study identifies 'what' types of knowledge SMEs gain from IT consultants. The study thus significantly improves our understanding of the intermediary role of consultants, as discussed by Howcroft \& Light (2008) and Carey (2008).

The study identified common knowledge sharing mechanisms used by consultants with SMEs. All four of the Boh \& Wong (2013) types of knowledge sharing mechanism were identified. Informal training (Q1) was the most commonly used mechanism, which was usually preceded by formal training (Q2). Other common mechanisms were informal (Q4) and formal documents (Q3) that detailed what tasks to undertake and the process for carrying them out. Desouza \& Awazu (2006) found that Nonaka's concept of socialisation (Nonaka et al. 2006) dominated the sharing of knowledge in SMEs, and that both formal and informal socialisation methods were used. The current study supports this observation, as the mechanisms used to facilitate knowledge sharing were formal and informal and involved socialisation with the consultants. This study found mixed support for Desouza \& Awazu (2006), who claimed that SMEs were good at exploiting external knowledge. While the current study found that SMEs used consultants to gain technical knowledge of AIS and to build accounting knowledge and skills, many other opportunities were spurned. For example, the SMEs did not seek to broaden their IT and project management skills by improving, for instance, their ability to identify the firm's IT needs, and to analyse potential IT solutions. In effect, the SMEs used consultants as a one-stop-shop for matters of accounting and AIS. Additionally, the people-based mechanisms observed by Desouza \& Awazu (2006) were also apparent in this study, for example face-to-face meetings, observations, and training. They argued that the predominant use of people-based mechanisms meant that knowledge generated is immediately put into practice. While the nature of IT may be such that the immediate application of knowledge occurs, the idea that knowledge management is based on people and not technology is noted in the current study. The only knowledge repository was the AIS database, and all other knowledge remained with individuals. However, informal codification mechanisms can quickly become formal codification mechanisms. For example, some of the manuals and procedures written voluntarily by users became the organisation's routine for AIS and accounting operations.

The current study also contributes by identifying what types of knowledge are shared during consultant/SME interactions. Importantly, the study identified three types of 'specialised knowledge' that consultants help to create: (i) experiential, such as know-how, hands-on, and trust; (ii) routine, such as established routines that facilitate learning; and (iii) systemic, such as reports generated from the software database (Chou \& He 2004). Thus, this study also improves our understanding of the kinds of knowledge assets that are created when consultants assist SMEs with the implementation of AIS. This is important because knowing what knowledge assets are created in SMEs may assist with the identification of tools and processes to aid SMEs with knowledge management. In addition to IT knowledge assets, the study found that consultants also helped with accounting knowledge.

While the majority of knowledge created initially is focused on use of the software, experiential knowledge assets such as trust, best business practice (accounting) and improvisation were evident. Such tacit knowledge equips the firm with the potential to turn routine use to benefit the organisation. Experiential knowledge assets dominate Boh \&Wong's quadrants Q1 and Q2; 
that is, informal personalisation and formal personalisation. Experiential knowledge assets consist of tacit knowledge that is built through hands-on or shared working experience (Nonaka et al. 2000). Tacit knowledge is personal knowledge held by the individual, based on the individual's subjective insight, intuition and hunches (Nonaka et al. 2000). This kind of knowledge is acquired mainly through association with other people and requires shared activities or experiences to beimparted from one person to another. Nonaka argues that shared experiences are vital for tacit knowledge to be shared. The shared experience involves using the software for various tasks with the consultant 'shadowing' the users. Such shared experiences and activities facilitate the sharing and development of tacit hands-on knowledge.

The study also clarifies the link between the use of external experts, like consultants, and the creation of knowledge assets in SMEs. While studies have indicated that knowledge from outside an organisation can come from consultants (Desouza \&Awazu 2006; Swanson 2010), this study clarifies these links by showing how consultants become a part of the knowledge creation processes in organisations like SMEs. Consultants, as part of the knowledge creation process, share various types of knowledge assets through numerous knowledge sharing mechanisms (Nonaka et al. 2000; Boh \&Wong 2013). As a consequence, consultants affect the know-how of firms as reported by Swanson (2010). The consultants interviewed in this study all indicated that it was in the interest of consultants to ensure that their clients gained sufficient knowledge of AIS (know-how), as this positively influenced the satisfaction of SMEs and increased the likelihood that the SME would engage the consultant on a regular basis. This also had the knock-on effect that the SME would recommend the consultant to other SMEs.

\section{Conclusions}

A series of interviews with managers of SMEs and with IT consultants helped identify three types of knowledge assets that were shared during IT implementation projects. The study, therefore, demonstrated that consultants have an impact on knowledge assets in SMEs. As a result, it is recommended that owners/managers, administrators and other users of AIS in SMEs take the opportunity to build knowledge assets while engaging consultants. In light of the findings of this study, managers and administrators should seek to create 'strategic partnerships' with consultants. The partnership suggested here should be aimed at developing the organisation's IT knowledge assets, thus ensuring that SMEs do not become totally dependent on consultants for AIS knowledge. This suggestion is in some ways similar to that given by Ko et al. (2005) who suggest that the relationship between consultant and client should be such that they interact frequently, which would facilitate the flow and interpretation of knowledge.

Consultants should view the process of implementing AIS in SMEs holistically, involving more than the selection and installation of software for the SME, but also the development of IT knowledge assets. Some consultants have already begun to embrace this view, and are encouraged to continue in order to assist SMEs to benefit by investing in IT as well as benefitting from deeper engagement with their consultant. An ideal way of influencing IT knowledge assets is to develop on-going relationships/partnerships with SMEs. It may be tempting to think that encouraging consultants to affect the knowledge assets of SMEs may not be in the interest of consultants. Such thinking is likely based on the idea that, as SMEs develop knowledge assets, they may no longer require the assistance of consultants. This view is misleading, since SMEs will continue to need the assistance of consultants as they develop their knowledge assets. An increase in the IT knowledge assets of SMEs is likely to result in a demand for greater use of IT, which will require assistance from consultants. Some of the consultants in this study noted that even when SMEs were knowledgeable, consultants still assisted with more advanced use of the system. Therefore, when consultants positively affect knowledge assets, it will be beneficial to both consultants and SMEs.

This study has a number of limitations. The study highlighted various knowledge assets that are shared by consultants. This may not be an exhaustive list. It is possible that there are other examples of knowledge assets created in SMEs but not identified by this study. However, this 
does not subtract from the overall finding that consultants assist in the sharing and creation of IT knowledge assets in SMEs. Another limitation is that the findings of this study may not be generalisable due to the small sample size and the use of a convenience sample. However, the findings are likely to be relevant to SMEs in comparable situations. Also, our findings may or may not be applicable beyond the AIS context. One other limitation of this research is that certain factors that may affect or mediate the findings of this study were not investigated. These factors include the attributes of consultants, the learning capability of employees of SMEs, and the reasons why SMEs implement IT.

The findings of this research and the above limitations reveal new opportunities for further research into IT consultants and SMEs. In particular, there is a need to examine further the factors that may affect or mediate the impact consultants have on IT knowledge assets in SMEs. For example, research could investigate the attributes of consultants; how do the abilities or skills of consultants affect the impact that consultants have on IT knowledge assets? Also, what effect does the reason behind the project have on the impact that consultants have on IT knowledge assets? Further, to what extent does the absorptive capacity of SMEs (that is, the "capacity of the recipient to assimilate, value and use knowledge and information transferred") affect the impact that consultants have on IT knowledge assets (Carayannis et al. 2012, p141)? And finally, what IT knowledge assets help predict IT success in SMEs?

\section{Acknowledgments}

The authors would like to thank the referees and, particularly, the editors, Craig Parker and Stephen Burgess, for their constructive comments in improving this paper.

\section{References}

Alavi, M. \& Leidner, D.E. (2001) "Review: Knowledge Management and Knowledge Management Systems: Conceptual Foundations and Research Issues", MIS Quarterly, 25(1): 107-136.

Basil, P., Yen, D.C. \& Tang, H.L. (1997) "Information consulting: developments, trends and suggestions for growth", International J ournal of Information Management, 17(5): 303-323. DOI: 10.1016/ S0268-4012(97)00013-3

Beesley, L. \& Chalip, L. (2011) "Seeking (and not seeking) to leverage mega-sport events in non-host destinations: The case of Shanghai and the Beijing Olympics", J ournal of Sport \& Tourism, 16(4): 323-322. DOI: 10.1080/ 14775085.2011.635016

Bessant, J . \& Rush, H. (1995) "Building bridges for innovation: the role of consultants in technology transfer", Research policy, 24(1): 97-114.

Boh, W.F. (2007) "Mechanisms for sharing knowledge in project-based organizations", Information and Organization, 17(1): 27-58. DOI: 10.1016/j.infoandorg.2006.10.001

Boh, W.F. \&Wong, S.S. (2013) "Organizational Climate and Perceived Manager Effectiveness: Influencing Perceived Usefulness of Knowledge Sharing Mechanisms", J ournal of the Association for Information Systems, 14(3): 122-152.

Carayannis, E.G., Pirzadeh, A. \& Popescu, D. (2012) "Epistemic Communities, Knowledge Transfer, and Institutional Learning", In: Institutional Learning and Knowledge Transfer Across Epistemic Communities, Springer,. 123-150.

Carey, J. (2008) "Role misconceptions and negotiations in small business owner/web developer relationships", J ournal of management \& organization, 14(1): 85-99.

Champion, D.P., Kiel, D.H. \&McLendon, J .A. (1990) "Choosing a consulting role", Training \& 
Development J ournal, 44(2): 66-69.

Chang, J .Y.T., Wang, E.T.G., Jiang, J J . \&Klein, G. (2013) "Controlling ERP consultants: Client and provider practices", TheJ ournal of Systems and Software, 86(5): 1453-1461. DOI: 10.1016/j.jss.2013.01.030

Chen, R.-S., J ih, W.-J ., Sun, C.-M. \& Helms, M. (2008) "Role Negotiation and Interaction: An Exploratory Case Study of the Impact of Management Consultants on ERP System Implementation in SMEs in Taiwan", Information Systems Management, 25(2): 159173. DOI: $10.1080 / 10580530801941371$

Chen, S., Duan, Y., Edwards, J.S. \& Lehaney, B. (2006) "Toward understanding interorganizational knowledge transfer needs in SMEs: insight from a UK investigation", J ournal of Knowledge Management, 10(3): 6-23. DOI: 10.1108/13673270610670821

Chou, S.-W. \&He, M.-Y. (2004) "Knowledge Management: The Distinctive Roles of Knowledge Assets in Facilitating Knowledge Creation", J ournal of Information Science, 30(2): 146-164. DOI: 10.1177/0165551504042804

Corbin, J .M. \& Strauss, A.L. (2008) Basics of qualitative research: techniques and procedures for developing grounded theory, SAGE, Thousand Oaks, Calif.

Curran, J . \&Blackburn, R.A. (2001) Researching the Small Enterprise, Sage Publications Ltd, GB.

Desouza, K.C. \& Awazu, Y. (2006) "Knowledge management at SMEs: five peculiarities", J ournal of Knowledge Management, 10(1): 32-43. DOI: 10.1108/ 13673270610650085

Durst, S. \& Edvardsson, I.R. (2012) "Knowledge management in SMEs: a literature review", Journal of Knowledge Management, 16(6): 879-903. DOI: 10.1108/ 13673271211276173

Easterby-Smith, M., Thorpe, R. \&J ackson, P. (2008) Management research, SAGE, London.

Gable, G.G. (1991) "Consultant Engagement for Computer System Selection: A Pro-Active Client Role in Small Businesses", Information \& Management, 20(2): 83-93. DOI: 10.1016/ 0378-7206(91)90046-5

Gable, G.G. (1996) "A Multidimensional Model of Client Success When Engaging External Consultants", Management Science, 42(8): 1175-1198. DOI: 10.1287/ mnsc.42.8.1175

Haines, M.N. \& Goodhue, D.L. (2003) "Implementation Partner Involvement and Knowledge Transfer in the Context of ERP Implementations", International J ournal of HumanComputer Interaction, 16(1): 23-38. DOI: 10.1207/S15327590IJ HC1601_3

Howcroft, D. \&Light, B. (2008) "IT consultants, salesmanship and the challenges of packaged software selection in SMEs", J ournal of Enterprise Information Management, 21(6): 597-615. DOI: 10.1108/17410390810911203

Hunter, M.G. (2005) "International Information Systems and Small Business Project: A western Canadian Perspective", In: M.G. Hunter, S. Burgess \& A. Wenn (eds) Small Business and Information Technology: Research Techniques and International Case Studies, Heidelberg Press, Heidelberg.

Hunter, M.G., Diochon, M., Pugsley, D. \& Wright, B. (2001) "Unique challenges for small business adoption of information technology: The case of the Nova Scotia Ten", In: S. 
Burgess (ed.) Managing Information Technology in Small Business: Challenges and Solutions: Challenges and Solutions, Idea Group Pub, Hershey, PA, p. 98.

Ifinedo, P. (2011) "Examining the influences of external expertise and in-house computer/ IT knowledge on ERP system success", The J ournal of Systems \& Software, 84(12): 20652078. DOI: 10.1016/j.jss.2011.05.017

J elavic, M. (2011) "Socio-technical knowledge management and epistemological paradigms: theoretical connections at the individual and organisational level", Interdisciplinary J ournal of Information, Knowledge and Management, 6: 1-16.

Ko, D.G., Kirsch, L.J. \& King, W.R. (2005) "Antecedents of Knowledge Transfer from Consultants to Clients in Enterprise System Implementations", MIS Quarterly, 29(1): 59-85.

Lech, P. (2011) "Knowledge transfer procedures from consultants to users in ERP implementations", The Electronic J ournal of Knowledge Management, 9(4): 318-327.

Lech, P. (2013) "Functional Consultants' Role in Enterprise Systems Implementations", 7th European Conference on Information Management and Evaluation, ECIME 2013, Reading, pp. 84-92.

Ministry of Business, Innovation and Employment (MBIE). (2013) The New Zealand Sectors report 2013: Information and Communications Technology, http:/ / www.mbie.govt.nz/ pdf-library/ what-we-do/ business-growth-agenda/ sectorsreports-series/ sector-report-information-communication-technology.pdf [accessed 1 February 2015].

Ministry of Business, Innovation and Employment (MBIE). (2014) The Small Business Sector Report 2014, http://www.mbie.govt.nz/ what-we-do/ business-growthagenda/ sectors-reports-series/ pdf-document-library/ the-small-business-sectorreport-2014.pdf [accessed 1 February 2015].

Nevo, S., Wade, M.R. \& Cook, W.D. (2007) "An examination of the trade-off between internal and external IT capabilities", J ournal of Strategic Information Systems, 16(1): 5-23. DOI: $10.1016 /$ j.jsis.2006.10.002

Nonaka, I. (1991) "The knowledge-creating company", Harvard business review, 69(6): 96104.

Nonaka, I. \& Takeuchi, H. (1996) "The knowledge-creating company: How Japanese companies create the dynamics of innovation", Long range planning, 29(4): 592. DOI: 10.1016/ 0024-6301(96)81509-3

Nonaka, I. \& Toyama, R. (2005) "The theory of the knowledge-creating firm: subjectivity, objectivity and synthesis", Industrial and corporate change, 14(3): 419-436. DOI: $10.1093 /$ icc/ dth058

Nonaka, I., Toyama, R. \& Konno, N. (2000) "SECI, Ba and Leadership: a Unified Model of Dynamic Knowledge Creation", Long range planning, 33(1): 5-34. DOI: 10.1016/S0024-6301(99)00115-6

Nonaka, I., von Krogh, G. \& Voelpel, S. (2006) "Organizational Knowledge Creation Theory: Evolutionary Paths and Future Advances", Organization Studies, 27(8): 1179-1208. DOI: $10.1177 / 0170840606066312$ 
Oates, B.J . (2006) Researching Information Systems and Computing, SAGE, London.

OECD (2012) OECD Internet Economy Outlook 2012, http://www.keepeek.com/DigitalAsset-Management/ oecd/ science-and-technology/ oecd-internet-economy-outlook2012_9789264086463-en - page1 [accessed 1 February 2015].

Ortiz de Guinea, A., Helen, K. \& Gordon, H.M. (2005) "Information Systems Effectiveness in Small Businesses: Extending a Singaporean Model in Canada", J ournal of Global Information Management (J GIM), 13(3): 55-79. DOI: 10.4018/jgim.2005070104

Schiuma, G. (2012) "Managing knowledge for business performance improvement", J ournal of Knowledge Management, 16(4): 515-522. DOI: 10.1108/ 13673271211246103

Soh, C.P.P., Yap, C.S. \&Raman, K.S. (1992) "Impact of consultants on computerization success in small businesses", Information \& Management, 22(5): 309-319. DOI: 10.1016/ 0378-7206(92)90077-S

Swanson, E.B. (2010) "Consultancies and capabilities in innovating with IT", The journal of strategic information systems, 19(1): 17-27. DOI: 10.1016/j.jsis.2009.12.001

Taylor, M. \& Murphy, A. (2004) "SMEs and e-business", Journal of Small Business and Enterprise Development, 11(3): 280-289. DOI: 10.1108/14626000410551546

Thong, J.Y.L. (2001) "Resource constraints and information systems implementation in Singaporean small businesses", Omega, 29(2): 143-156. DOI: 10.1016/S03050483(00)00035-9

Thong, J.Y.L., Yap, C.-S. \& Raman, K.S. (1994) "Engagement of External Expertise in Information Systems Implementation", Journal of Management Information Systems, 11(2): 209-231.

Thong, J.Y.L., Yap, C.-S. \& Raman, K.S. (1997) "Environments for Information Systems Implementation in Small Businesses", J ournal of Organizational Computing and Electronic Commerce, 7(4): 253-278. DOI: 10.1207/ s15327744joce0704_ 1

Wang, E.T.G. \& Chen, J.H.F. (2006) "Effects of internal support and consultant quality on the consulting process and ERP system quality", Decision Support Systems, 42(2): 10291041. DOI: $10.1016 /$ j.dss.2005.08.005

Werner, K., Dickson, G. \& Hyde, K.F. (2015) "Learning and knowledge transfer processes in a mega-events context: the case of the 2011 Rugby World Cup", Tourism management, 48: 174-187. DOI: $10.1016 /$ j.tourman.2014.11.003

Yeşil, S. \& Hırlak, B. (2013) "An empirical investigation into the influence of knowledge sharing barriers on knowledge sharing and individual innovation behaviour", International J ournal of Knowledge Management (IJ KM), 9(2): 38-61.

Yin, R.K. (2003) Case study research: design and methods, Sage Publications, Thousand Oaks, Calif.

Yoon, S. \& Suh, H. (2004) "Ensuring IT Consulting SERVQUAL and User Satisfaction: A Modified Measurement Tool", Information Systems Frontiers, 6(4): 341-351. DOI: 10.1023/ B:ISFI.0000046376.10364.16 
Copyright: (C) 2015 Bradshaw, Pulakanam, Cragg. This is an open-access article distributed under the terms of the Creative Commons Attribution-NonCommercial 3.0 Australia License, which permits non-commercial use, distribution, and reproduction in any medium, provided the original author and AJ IS are credited.

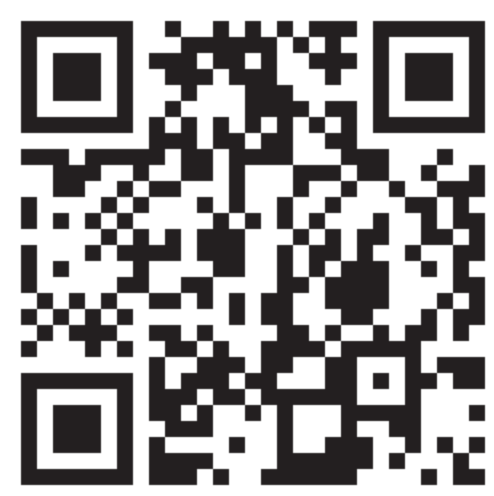

